\title{
THE ISLAM-ORIENTED HOUSE STRUCTURE IN KANO: A VANISHING HERITAGE IN MODERN CITY COMPOSITION
}

\author{
Ahmad Yahya
}

\author{
Department of Islamic Studies \\ Federal College of Education PMB 3045 \\ Kano State, Nigeria \\ email : ahmadfaggekano@yahoo.co.uk
}

\begin{abstract}
The debut of colonialism along with the consequent de facto supremacy of the Western world did not only negatively impact on the economy and polity of the Muslim world. It has also, to some reasonable extent, polluted the social system, particularly the structure and form of cities. Human scale is gradually diminishing as a yardstick for construction and is being replaced by a mathematical one. Collectivism, which used to characterize Muslims' social set-up, is now being over-shadowed by stark individualism. The Islamic social values which used to be the binding force that held Muslims together are now being crushed by moral relativity. The situation becomes so chronic that many people begin to assume that Islam has a very negligible role to play in the formation and construction of modern cities. Kano, a predominantly Muslim state in NorthWestern Nigeria, inherited a thousand year-old Islam-oriented building architecture which made it a model Islamic city in pre-colonial Africa. Of special reference is the residential structure which no doubt reflects Islamic culture. Unfortunately, this age-old heritage is now being pushed to the brink of extinction by the almighty modern architecture. This paper explores the Islamic in the Kano traditional residential structure and attempts to comparatively bring into light the extent to which it is diminishing in the modern building architecture. The paper suggests blending the two for a peaceful and harmonious co-existence.
\end{abstract}

Keywords: islamic values, Kano traditional settlement, modern architecture

\begin{abstract}
Abstrak
Kolonialisme dari dunia Barat tidak hanya berdampak negatif terhadap perekonomian dan pemerintahan dari dunia Muslim. Hal ini juga mempengaruhi sistem sosial, khususnya struktur dan bentuk kota. Skala bangunan yang manusiawi semakin berkurang dan tergantikan oleh konstruksi dengan standar matematis. Kolektivisme, yang digunakan untuk mengkarakterisasi dunia Muslim, sekarang dibayangi oleh karakter individualisme. Nilainilai sosial Islam yang digunakan untuk menjadi kekuatan yang mengikat dunia Muslim sekarang sedang dihancurkan oleh relativitas moral. Situasi menjadi begitu kronis dan banyak orang mulai menganggap bahwa Islam memiliki peran yang minim dalam pembentukan dan pembangunan kota modern. Kano, sebuah negara mayoritas Muslim di Utara-Barat Nigeria, mewarisi arsitektur yang berorientasi pada nilai nilai Islam yang telah ada ribuan tahun dan membuatnya menjadi model kota Islam pra-kolonial di Afrika. Dari referensi khusus yang ada, warisan ini adalah struktur perumahan yang tidak diragukan lagi sangat mencerminkan budaya Islam. Sayangnya, warisan ini sekarang sedang diambang kepunahan oleh arsitektur modern yang mendominasi. Makalah ini membahas Islam dalam struktur perumahan tradisional Kano dan mencoba untuk merefleksikan dalam bangunan arsitektur modern. Makalah ini berusaha untuk melihat penggabungan keduanya untuk menciptakan harmonisasi lingkungan.
\end{abstract}

Kata kunci: nilai-nilai Islam, rumah tradisional Kano, Arsitektur modern

\section{Introduction}

This paper is an attempt to bring into light the landmarks of Islam in the formation and construction of cites as they affect Hausaland, taking Kano as an example. The paper explains the concept of city in Islam and examines Al-Madinah Al-Munawwarah as the first ideal Islamic city. An elucidation is made on the contact of Islam with and its influence on Hausaland, particularly Kano, as per the construction of residence. The paper examines the traditional house structure in Kano and explains the extent to which it is Islam-oriented. Also discussed is the gradual decline of this heritage and its replacement by residences that can be best described as westernoriented.

\section{Islam and urbanization}

A study conducted less than a decade ago indicates that more than half of humankind will, by the end of the $20^{\text {th }}$ century, live in urban areas and up to $60 \%$ by the year $2020^{1}$.

One of the basic missions of Islam is emancipation of the humankind from the shackles of 
superstition, witchcraft and other forms of ideological slavery. This is followed by ennobling human behaviour and adorning it in such a way that human becomes distinct from other creatures. Next is stressing collectivism and obliteration of atomism along with its regalia.

Some scholars are of the view that Islam is urban and it is the urban setting which facilitated its successful spread in the world ${ }^{2}$ because people saw in it a civilizing force besides its spiritual benefits. One scholar admits that it 'supplied the creative element out of which arose a new civilization' ${ }^{3}$. Many communities in Africa embraced it because they were offered great improvement in their lifestyle, including principles of communal living ${ }^{4}$. Along this line it is observed that:

Among the most fundamental and compelling archetypes has been the notion of the Ummah, the emblem of Muslim religious and social universe. The charge of revaluing the urban structure in accordance with the ideals of the Ummah-and moreover, all of its complexities, cultivated a unique and robust configuration of urban space, the product of which was a fusion between the dictates of the faith and the practical matters of urban living. The assertion of this new-found identity thus indicates the epitome of the Islamic city ${ }^{5}$.

As the microcosmic nucleus was formed in the cities of Makkah and Madinah it is not surprising that in many parts of the world, since the first century of the Hijrah, the Islamic community proliferated cities. This central position which urbanism and of course city acquire in Islam may not be unconnected with its aim of evolving a unique model community on earth. A scholar avers that:

...classical antiquity could not separate
civilization from city life. It was the cities
which secured conquered territories for
Hellenism. Islam, too, needed the city as a
base, and it needed it as the only locale in
which the correct life as prescribed by the
Book of God and the Prophet's Tradition
could be lived out to the full ${ }^{2}$.

This led some scholars to conclude that the islamic community is essentially urban ${ }^{6}$.

It is important at this juncture to point out that urbanism of a community is not only based on having a large number of people or comprising multiple settlement areas. It is also measured with having a unanimously recognized and acknowledged leader, who is capable to deliver and trustworthy as well as possesses all qualities of a good leader. He avails to all and sundry of the right to criticize and suggest ${ }^{7}$.

\section{Stages of urbanization}

The process of urbanization comprises four stages. These are explained as under:
1. The first stage is characterized by the core of the city being small with its inhabitants and buildings being few. Only primitive tools are used in building which is also rustic.

2. The second stage is marked by abundant city planning, appearance of sophisticated building materials and growth in population. Pace of building picks up and activity becomes more intense.

3. In the third stage building comes to a halt and population recedes. Consequently work vanishes as a result of the dwindling population. This obviates a quest for more building materials. The latter are substituted by material salvaged from existing structures.

4. In the fourth and final stage a rustic way of building is reverted to. This signifies a return to square one. The pace is now that of simplicity and deterioration of civilization. Eventually, Allah raises up a new generation ${ }^{8}$.

\section{The city in Islamic perspective}

Human being, by his very nature, is civic (Muduni). This means that he is a being whose survival, welfare and existence as a whole spring from communal origin. He can only thrive, exist and survive with the help of interacting and interrelating with others, as a matter of necessity ${ }^{9}$. He cannot survive alone and independent of others. Whatever happens to the individual stems from communal frame and whatever happens to the community is inherently related to the individual. Human being therefore can be said to be naturally more inclined to collectivism than to atomism. This is why an area is referred to as a city if it contains a large number of people. This is partly due to the high rate of interaction, which is natural to human being. The benefit is even greater when there are people of diverse cultural, ethnic and religious backgrounds. This is because besides increasing the degree of inter-dependence there is also the benefit of sharing cultures, ideas, zealousness, etc. of others. As Islam is a faith which is congruent with the human nature, a Muslim therefore naturally interacts, agrees to differ and be differed from.

The care and concern of Islam over what pollutes the society should not be over emphasized. Material as well as moral integrity is the sacred right of all which no one must infringe upon. This explains, and Allah knows best, why most of the crimes that are punishable or retaliatable in Islam are those that threaten the unity, moral integrity and material prosperity of the society ${ }^{10}$.

Islam encourages a harmonious co-existence of the natural, built and social environments which can be realized through maintaining equilibrium between the natural environment and the natural forces and elements. This explains why, throughout Muslim history, the natural forces and elements have been maximally made use of. In hot areas like Kano, for instanc, narrow streets were constructed to preserve the cool night air during the hot hours of the day. Ideal buildings are, as inferred from the Qur'an (3:198, 9:72, 32:19, 4:57, 76:13-14, 77:41-42), those 
that are built amidst natural environment. The Muslim is taught to regard the natural environment as a fellow creature, the harming of which will be retaliated on the Day of Reckoning. He therefore lives peacefully with $i^{11}$. (Rahman: 2005).

One of the conventional definitions of a city is a place with a minimum of ten thousand people and with a municipality which should consist of at least five thousand people ${ }^{12}$ (Saremi: 2008). What should be taken into cognizance is the fact that the determining factor in integrating Islamic societies is the concept of unity in diversity ${ }^{13}$ (Martin as quoted by islamicart.com).

The correct definition of a city in Islam is a place where a large number of people (may be of different backgrounds) dwell with equity and fairness, guided by laid down rules and in which multi-dimensional interests of the people are appropriately taken into consideration. The city in Islam 'offers a pervasive movement and repeated in the metropolis in which every man was received equally as one of God's servants, and might try his fortune ${ }^{14}$.

Islam lays down some guidelines in order to make interactions sober, sound and healthy. These guidelines govern the relationships between neighbours, parents and their children, brothers, husbands and wives, rich and poor, rulers and the ruled, knowledgeable and ignorant, men and women, indigene and stranger, Muslim and nonMuslim, young and old, etc. These combine to make the Muslim developed and the Muslim community civilized.

\section{Categories of buildings in Islamic city structure}

The five values of Islam leave no stone unturned as far as human activities are concerned. These are the obligatory, the prohibited, the recommendable, the disliked and the allowed. Construction, by its form and nature, encompasses human activity in its entirety. It therefore encompasses man's intellectual, economic and aesthetic activity ${ }^{15}$. Buildings, according to Islamic perspectives pertaining city structure, are categorized as follows:

1. The necessary buildings: places of worship such as mosques, walls and outposts which serve as a protection for the lands of Islam and fortresses fall under this category. This is why many Muslim cities were walled and full of mosques. In Kano there is the Badala, which was a wall that surrounded the city, stretching to about 25 kilometres. Though it is neglected and left at the mercy of mud-brick makers, its remnants are still visible.

2. The recommended buildings: included in this category are minarets which serve the purpose of Adhan (call to prayer) and markets for buying needed items and for easing hardship in procuring them. The oldest market in Kano is the Kurmi market which still thrives.

3. The permitted buildings: These include houses which serve to protect life, property, honour and integrity of people. The family, which is the pivot of the Islamic social system springs from and thrives in the house. Life, property and honour rank among the indispensables of Shari'ah.

4. Proscribed buildings: these include buildings that shelter abominable acts such as brothels, bars, casinos, buildings on graves, buildings on encroached lands and buildings on lands belonging to others ${ }^{8}$.

History bears witness to the fact that brothels, bars and casinos emerged in Muslim cities after the debut of colonialism which destroyed all the fabrics of Islam in the colonies. In Kano, during the reign of Emir Abbas, residences inherited by women began to be converted into quasi-brothels. When this was discovered an order was issued that henceforward only monetary value of houses would be given to women if such residences should fall under their inheritance. This short-lived order helped to ameliorate the situation ${ }^{16}$.

\section{Aims of building cities in Islam}

Ostentation, arrogance, superiority complex, atomism, unguided and unrestricted freedom stripped of religious attire are not what cities are meant for, as far as Islam is concerned. The basic aim is to strengthen the cohesion of Muslims in particular and the entire human race in general. The Qur'an (4:1) says:

O mankind! Reverence your Guardian-Lord, who created you from a single person, created, of like nature, his mate, and from them twain scattered (Like seeds) countless men and women;- reverence Allah, through whom ye demand your mutual (rights), and (reverence) the wombs (That bore you): for Allah ever watches over you.

The Prophet of Islam, upon whom be Peace, explains further that:

People are children of Adam and Adam was (created) from clay ${ }^{17}$.

As for the unity of the Muslim community as one family the Prophet, upon whom be Peace, is reported to have said:

(The simile of the) believer ('s relationship) to (another) believer is like (that of) a building, each part supporting the other ${ }^{18}$.

He is also, in another instance, reported to have said:

You will find believers in their compassion, love and affection to one another to be like a body which its entirety stings and pains when an organ is harmed ${ }^{18}$.

This can be realized when people of different ethnic, cultural and religious backgrounds are brought together to live as one family and as one body. During the reform of Shehu Usmanu Danfodio in Hausaland the Jihad leaders built cities and mosques in order to make Islamic unity strong, educating people and assigning them different responsibilities to manage society's needs ${ }^{19}$. 
Basic requirements for a city in Islam

By its nature Islam, as already indicated, is an urban religion. This is largely because it favours communal practice over individual worship. Urban in this context means communal. Most of Islam's aspects of worship, belief and values emphasize social gathering and discourage isolationism or nomadism. A city is no more than a mechanism by which rules of the society can consolidate and maintain their power. Islam lays much emphasis on peace and security which result to prosperity in any social set up. These three are considered to be main ingredients for urban rejuvenation and growth ${ }^{20}$. In Madinah, the Prophet, upon whom be Peace, introduced a new concept in urban setting. Good and sound neighbourhood was portrayed by him as the unit of community formation which eventually results to a city. The western world imbibed this concept thirteen centuries later and refers to it in their writings as urban community, urban village, traditional neighbourhood, etc.

Conventional standards demand that a city should have a substantial number of people and must have a municipality. In addition to this Islam, taking into cognizance al-Madinah al-Munawwarah (the illuminated city) lays emphasis on the social dimension as well. There was a unanimously agreed leadership of the Prophet, upon whom be Peace, in whom Allah combined all the qualities of a good leader. He administered the affairs of the community with justice and fairness, guiding it to all that is good and turning it away from evil. Above all he implemented the Shari'ah, a Devine code of life. Secondly, there was the community comprised of people who were kind, compassionate, considerate and caring to one another. Their pride lied not in aboriginality but in being the servants of Allah. Each of them was ready to sacrifice anything for the sake of the leader, the system and the entire community. Thirdly, there was a constitution in the form of Divine Revelation (the Qur'an) which has man's spiritual, moral and material development as its topmost priority. Moreover, this constitution contains no contradictions or obscurities whatsoever ${ }^{21}$.

\section{Islamic injunctions pertaining to living in cities}

The distinguishing feature of a city, in Islamic perspective, which makes it distinct from a village and Bedouin life, is large number of people. Islam always lays emphasis on what is communal. Praying in congregation, for example, carries more reward than performing it alone. A prayer is stipulated once in a week to be performed in a very large congregation. Another type of prayer is performed twice in a year and in a mammoth congregation. In cases of moon sighting the testimony of a large number of people is preferred. The Prophet, upon whom be Peace, is reported to have said:

$$
\text { Community is a mercy }{ }^{22}
$$

He is also reported to have discouraged a Bedouin life or living in isolation:
'He will become harsh-tempered he who lives in isolation'

Sheikh Muhammad Bello, one of the leaders of the $19^{\text {th }}$ century Islamic reform movement in Hausaland and a son to Sheikh Usmanu Danfodio ${ }^{19}$ (as quoted by Hakim and Ahmed: 2006) explained that it is only a Fitnah (crisis) which will force people to escape the city. Therefore, living in villages is better than living as a Bedouin and living in cities is better than living in villages

\section{The first Islamic city}

It is generally accepted that the first ideal Islamic city was al-Madinnah al-Munauwarah. Formerly called Yathrib the Prophet, upon whom be Peace, upon his arrival, changed its name to alMadinah, meaning 'the ideal Islamic city'. This shows one of the zenith of the Prophet's aspirations which is to bring a large number of the Muslims together under Prophetic leadership and bound together by a strong Islamic unity, worshipping Allahu Ta'ala without any restraint.

The Prophet, upon whom be Peace, was born in Makkah, which was a city and migrated to Madinah, which was also a city. It was there that the greater portion of the Qur'an was revealed. After migration, the Prophet, upon whom be Peace, embarked on proper planning of both the social and physical environment. A polity was established where:

The main theoretical ingredients of Islam were fully put into practice. Relationship between the community members was based on Islamic brotherhood to such an extent that a Madinite would share all what he had with a Muhajir ${ }^{2}$.

The first thing which the Prophet, upon whom be Peace, did was building a mosque. This indicated two things:

1. That Allahu Ta'ala and His worship should always be superior and the common goal of all Muslims in every settlement;

2. That one should live as and be proud of being a servant of Allah whom He creates out of His Mercy. This negates the philosophy which requires one to be proud of being human who evolved and emancipated himself from the socalled merciless grip of the gods.

After the construction of the Prophet's mosque he then built a home which was an indication of its being a primary and important unit in a city structure. An area close to the mosque was designated to be a market where commercial activities would ensue without being unmindful of the prayer. Roads were then built. Smaller roads measured five arm lengths which would comfortably allow two camels to pass by one another. Bigger roads measured ten arm lengths. When the Prophet's companions built the cities of Basrah and Kufah small roads were constructed to measure ten arm lengths while bigger ones measured sixty arm lengths 23 . 
After building his house, market and roads the Prophet, upon whom be Peace established a brotherhood between the Muhajirun (companions who migrated to Madinah from Makkah) and Ansar (the people of Madinah) to actualize and symbolize the aim of living in cities which is to strengthen social unity. The city of Madinah, under the Prophet's leadership, brought both Muslims and Jews together as brothers and keepers of one another.

It can therefore be understood that the Prophet, upon whom be Peace, established an ideal city and an ideal urban community in Madinah under the guidance of a revealed constitution ${ }^{24}$. The first model of Islamic city was therefore al-Madinah alMunauwarah ${ }^{25}$.

\section{Hausaland and its contact with Islam}

Islam was once the predominant religion in more than half of the civilized world. It stretched over three continents from Pyrenees and Siberia in West and North Europe to the farthest end of Asia, up to China and New Guinea in the East. From Morocco in North Africa to the southern tip of Africa, covering two-thirds of the African continent ${ }^{26}$. In West Africa, activities of the Sufi orders, Muslim traders, itinerant scholars and reformers facilitated its spread. The role of conquest was very negligible ${ }^{27}$.

Hausaland was located in the Central Bilad alSudan bordering Kanem Bornu in the east and Songhai in the west ${ }^{28}$. Today Hausaland covers Northern Nigeria and Niger Republic. It is borderd by Borno in the east, Dahomey in the west, Adar in the north and by Gwari and southern Bauchi tribes in the south $^{29}$. Hausa itself is a multi-ethnic society. The bulk of the inhabitants are believed to have migrated into the region sometime before $10^{\text {th }}$ century from the central Sahara. They settled in the central Savannah and mixed with the indigenous people. This resulted to multi-ethnic society, sharing a common language, Hausa ${ }^{28}$.

Islam spread into this part of the world since $8^{\text {th }}$ century ${ }^{30}$. Islamic social values and the traditional Hausa way of life have inter-mixed for such a long time that many basic tenets of Hausa society are Islamic. Islam has, for quite sometime, been a very powerful social landmark in the acculturating frontiers of Hausa as an ethnic group both at home and in migration ${ }^{31}$.

\section{Kano: A historical overview}

Kano originated as a spiritual centre in which Tsumburbura, the then acclaimed deity, was housed at the Dala hilltop under Barbushe. With gradual increase in population other chieftains resided at other defensive sites along with their followers. Kano became an important commercial and manufacturing centre during the Bagauda dynasty between $10^{\text {th }}$ and $11^{\text {th }}$ centuries $^{32}$. When Sarki Yaji Dan Tsamiya (1349-1385) was converted to Islam by a group of fourty Wangarawa missionaries from Mali under the leadership of Abdur-Rahman al-Zaiti he built the first mosque 29 . However Islam had been there more than 3 centuries earlier. The period of
Sarki Yaji Dan Tsamiya (1349-1385) was the time during which Islam became a state religion in Kano

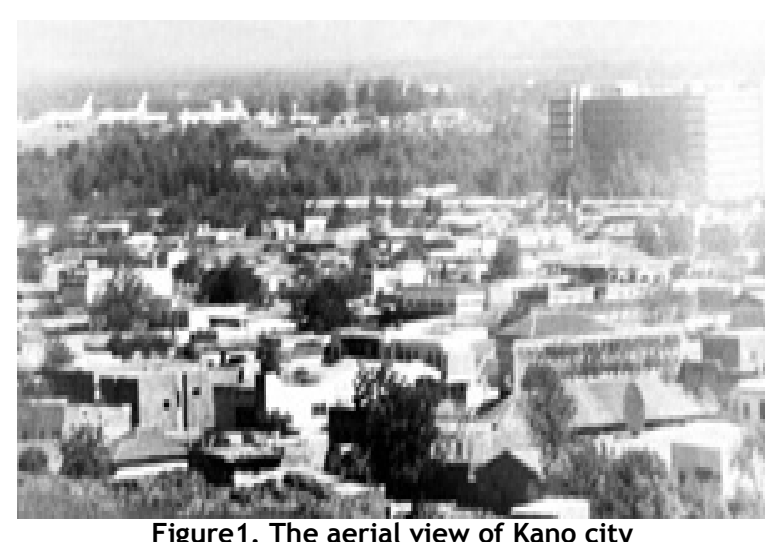

Sarki Gazarzawa built the first Badala (protective wall $)^{33}$ which was fortified by Sarki Muhammadu Rumfa (1467-1499) to incorporate a large area in the south-western part of the city ${ }^{32}$. Further additions to the city which defined the limit of the Badala space were effected by Sarki Muhammadu Nazaki (1582-1618).

Emirs of Kano after the Jihad of Shehu Usmanu Danfodio established sub-urban settlements outside the Badala as Gandu (summer place). Telegraphic communications linked Kano with the coast during the British colonialism in $1904^{33}$. As at 1903 Kano contained an estimated number of 170 walled towns indicating 'a symbiotic relationship between rural and urban dwellers for a long period of time ${ }^{\prime 34}$. By 1911 a railway line was extended from Lagos to Kano. This hampered the commercial and industrial position of Kano.

Today Kano is one of the thirty six states of the Federal Republic of Nigeria, lying between Latitude $13^{\circ} \mathrm{N}$ in the North and $11^{\circ} \mathrm{N}$ in the south and Longitude $8^{\circ} \mathrm{W}$ in the west and $10^{\circ} \mathrm{E}$ in the east. It is made up of 44 Local Government Areas. Its total land area is 20,760 Square Kilometres. Kano City is located on Latitude $12.00^{\circ} \mathrm{N}$ and Longitude8. $30^{\circ} \mathrm{E}$. It became a state in $1964^{35}$.

Kano is some Kilometres from the edge of the Sahara Desert and some 1140 Kilometres away from the Atlantic Ocean. It borders Jigawa state by the north and east, Katsina and Kaduna states by the west and south-west respectively and Bauchi state by the south-east. Kano has a population of $9,383,682$ according to the 2006 National Census, majority of which are Muslim Hausa and Fulani.

\section{Categories of settlements in Kano}

Settlements in Kano can be categorized into three:

a. Pre-colonial: comprising the old city (and Fagge) in which avail most of the Islam-oriented houses.

b. Colonial: comprising areas such as Sabongari, Tudun Wada and Nassarawa.

c. Post-colonial: comprising Hotoro, Na'ibawa, Kurnar Asabe, etc ${ }^{34}$.

Today there are over two thousand mosques in Kano. This includes the roadside praying enclosures 
and a minimum of 20 Jumu'ah mosques located in various parts of the metropolis.

\section{Urbanistic elements in Kano}

In present day Kano three distinct urbanistic elements can be isolated, each with different urban features and peculiar physical morphology. These are:

1. The traditional walled historical city with its traditional spatial character and largely traditional architecture. This part is called Birni.

2. The industrial and stranger districts which are laid out on a regular geometric pattern, based on imitation of foreign models.

3. The functionally laid out European quarters with a high standard of facilities, European types of housing and plenty of greenery. It was initially racial-based, particularly in the preindependence time, but now largely occupied by top government functionaries ${ }^{32}$.

Present-day Kano urban society is dichotomized into the walled city dwellers and those outside it (Waje). Autochthonous Kano people lived in the former and stranger elements originally constituted the latter. The walled city housed almost all the most important traditional cultural institutions such as Kurmi market, Dala hilltop, Gwauron Dutse hilltop, Emir's palace, central Friday mosque, etc. Modern institutions and amenities, on the other hand, cluster outside the walled city.

The cosmopolitan nature of Kano was attested to by some European scholars, such as Birth, who visited Kano in 1851. People of diverse ethnic backgrounds were found, since that time, to live with one another in peace and harmony ${ }^{34 .}$

\section{The structure of residence in urban Kano}

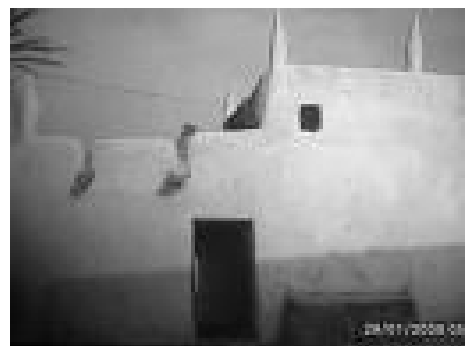

Figure 2. The kofar gida with dakali alongside its wall

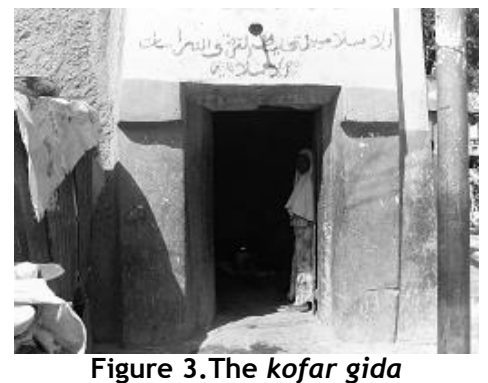

The house or residence is the building block of cities, hamlets, towns, conurbans, etc. One scholar observes that:
The dwelling unit is the basic cellular element of the city. Its multiplication produces an urban form, the success or failure of which in promoting privacy depends on the sort of physical interrelationships set forth between these units ${ }^{36}$.

House in urban Kano is divided into three realms:

a. The public realm.

b. The transitional realm

c. The private realm

\section{The Public Realm}

The public realm comes first, followed by the transitional and finally the private realm. In the public realm there are basically four things. First comes the wide and spacious forecourt (Filin Kofar gida), followed by a single main entrance (Kofar gida) positioned in a battered wall which is thicker at the bottom and thin at the top. It is observed that 'Hausa builders have learned, through accumulated experience of many generations, that the stability of a wall is increased by decreasing the thickness of the wall towards the top...' ${ }^{37}$. Aligned with this wall by one side or both sides of the main gate of the house are seats made of clay and mud bricks (Dakali) for resting and/or waiting. What one sees next is the main entrance hall (Zaure) which is so wide and deep that it can comfortably accommodate a very long ladder. All are allowed to be at the forecourt while only the permitted ones can have direct access to the entrance hall except, perhaps if the main entrance is closed or locked.

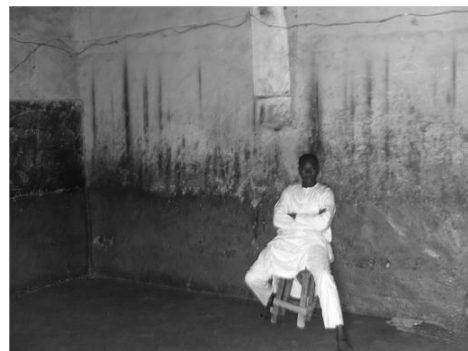

Figure 4. The entrance hall (zaure)

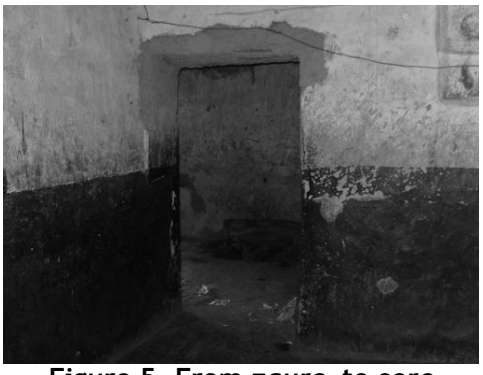

Figure 5. From zaure to soro

The Transitional Realm

The transitional domain is what comes next. This is because it serves as a link between the public and the private realms. The entrance room (Soro) or rooms (Soraye) and in some instances, such as in the houses of the affluent or chiefs, the special reception area (Kudandan) are what this part of the house contains. The Soro comes immediately after 
the Zaure. The number of Soro may be two, three, four or even more, depending on the social or economic status of the owner. These Soraye (plural of Soro) have entrances positioned at different angles and of varying sizes. The first Soro is larger than the second one and so on. The last one is the narrowest. Some houses, particularly those of chiefs and rich people, have a special reception area called Kudandan or Shamaki. It is normally positioned inbetween the second to the last and the last Soro. It is reserved for receiving special guests. It may be roofed or roofless and normally protrudes to the right. The last Soro is followed by a U-shaped corridor which opens to the inner courtyard of the house (Cikin gida).

\section{The Private Realm}

In the private realm what one sees first is the Turaka or the house master's separate area (in some cases). It contains a large parlour inside which there is a bedroom and at another angle the toilet. In some cases foodstuff are stored there. Except the house master or his wife/wives, nobody goes there. In some houses a separate part for the mother of the house master comes next which also contains a parlour inside which there is a bedroom and a toilet. What comes next is a very wide and spacious open courtyard. Its size depends on the magnitude of the family, the socio-economic or the political status of the owner ${ }^{38}$.

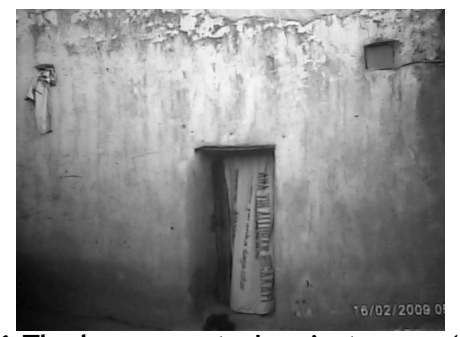

Figure 6.The house master's private area (turaka)

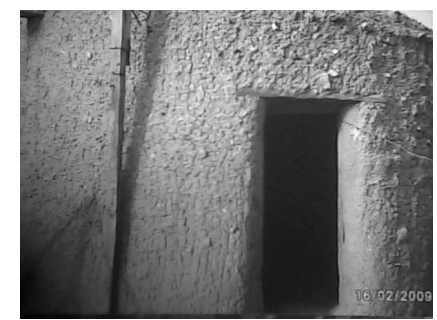

Figure 7. The special reception area (kudandan)

The open courtyard modifies the climate and allows for outdoor activities with protection from wind and sun in very hot areas like Kano. It also serves as an air well into which the cool, night air can sink ${ }^{39}$. As traditional house in urban Kano is highwalled with few or no windows it withstands severe elements like hot winds and blown sand. Positioned at the far end of this open courtyard is a large parlour (Rumfa) that houses the wives' rooms and a female guest room. There is a single entrance to it from Tsakar gida and two coverless windows high on top of it. The roofing is dome-like (Daurin guga).
There is a reasonable distance between rooms in such a way that no door or window of a room directly faces the opposite room. Similarly, no sound or movement from one room could be heard in another room. This parlour contains the innermost and the most private part of the house. This is the bedroom or Daki It serves not only as a sleeping place but also as an area that keeps valuable items ${ }^{38}$.

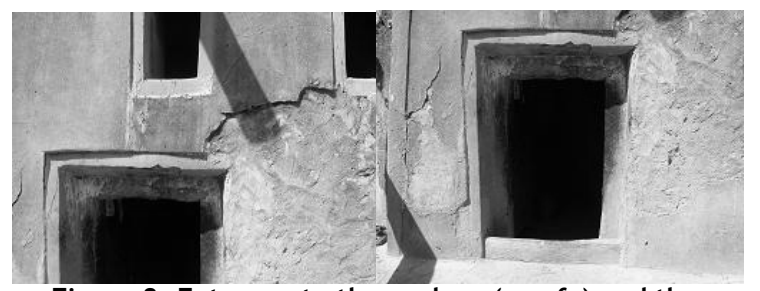

Figure 8. Entrance to the parlour (rumfa) and the coverless windows on top of it

In the wife's room, on the right, is a short mud barrier called Ingurfuni or Babbaka. It begins some distance by the right from the entrance and stretches to about 2.5 metres, leaving a gap from the other wall. This gap serves as a passage to the inner room. Height of this barrier does not reach up to the room's ceiling ${ }^{16}$. The room is thus partitioned into Farfajiya (outer part serving as a reception area for special female guests) and Kurya (the inner part where the bed, in some cases, made up of mud, is positioned). Lamp hole (Alkuki) is carved in the wall and pot for storing cool drinking water (Randa or Tulu), with a cover (Faifai), rests on the floor against the mud barrier. Suspended from the room's ceiling by a rope is a container pendulum (Ragaya) in which very personal and vital items such as money, thread, needles, cotton, etc., are kept.

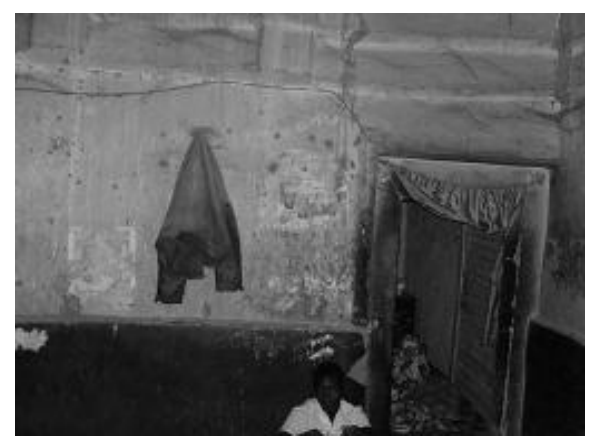

Figure 9. A wife's daki in the rumfa

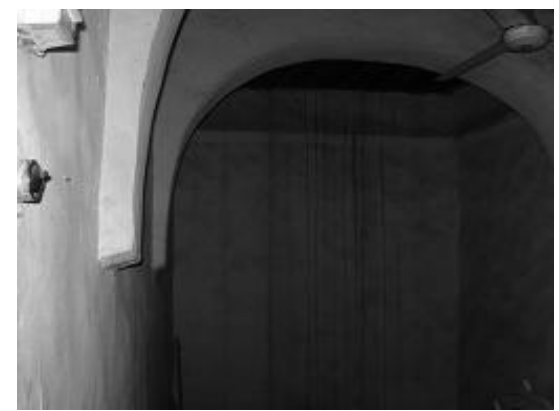

Figure 10. The innermost part of the room (kurya) 
Toilet is positioned at a reasonable distance such that the young might need the company of an adult to access it. It is designed to serve two purposes; bath and stooling. What one sees first is a wide space for taking bath. Next is the stooling area which is raised some inches above the level of the bathing space. At the edge of the pit designated for defecating, a sloped drainage is made to the west. One is expected to squat on the pit facing the west which is where the sloped drainage is while turning his back to the east.

\section{Evolution of residence in urban Kano}

In urban Kano residence can be said to have passed about four phases. Phase one was when the population was small. House in this phase was very large, wide and extremely spacious. This might partly be due to readiness to accommodate others, relative or otherwise. Thickness of a wall, for example, might measure up to six feet. There were no storey buildings partly because of the availability of vast land. There was no single room without an attached parlour. The Turaka area alone can make a full house today.

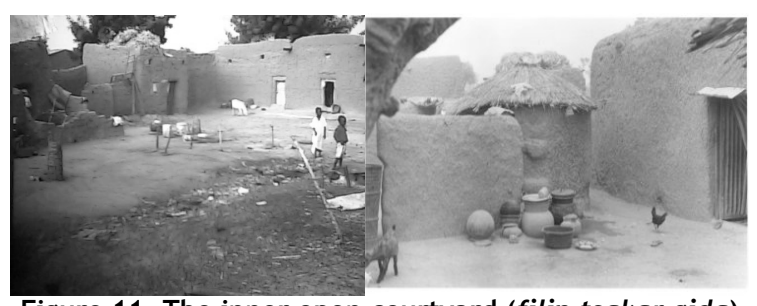

Figure 11. The inner open courtyard (filin tsakar gida)

The second phase was when the population started to expand. Size of houses began to decrease. The size of Zaure and the number of Soraye, for example, started to lessen. The open courtyard became narrower. Multi-storey buildings emerged but with very narrow windows which from inside could not be reached by a very tall person. Single rooms began to replace rooms enveloped by a very wide and spacious parlour.

The third phase was characterized by the gradual elimination of Zaure and its replacement with shops (Shago) used for either sleeping or commercial purposes. Size of the open courtyard and that of Zaure were grossly reduced. Separate house or houses within a house began to appear, possibly due to disputes over inheritance or buy-over.

The fourth, which is the final phase, is generally characterized by dearth of space and the desire to congest in the municipality. Consequently, the price of plots of land became exorbitant. House structure became completely alien and divorced from the indigenous religion and culture. Zaure, Soro, Filin kofar gida, Filin tsakar gida, etc., all disappeared. Shago now replaced Soro while Zaure is replaced with sitting room. Open courtyard is now very much narrow or even extinct.
A House (Gida) as perceived by Kano people

Concieving residence as a sleeping place cuts across most cultures, tribes and nations. The primary function of a house is to provide a sleeping place and protection against rain, cold or sun heat. However, to the Kano people, a house should do more than this as there are many equally important functions expected of an ideal house.

Protection, preservation and safeguard of one's dignity, self-respect, honour, esteem, faith and mark of distinction are the primary purposes of a house. This is because in a Muslim Hausa society, like Kano, one is considered responsible (Mutum mai mutunci) whose association should be sought and cultivated when he is dignified, honourable and worthy of respect ${ }^{40}$. The perception of a house can therefore be summed up in (but not necessarily limited to) the following:

1. It is a safeguard of the owner's integrity, privacy and personal secrets.

2. It is a place for socialization. Occasions such as wedding ceremony, naming ceremony, social discourse, funeral, courtship, investiture, circumcision and (sometimes) internment take place in the house. It therefore constitutes one's social garment and a pre-requisite for personal integrity.

3. It is an avenue for inculcating and enhancing the spirit of brotherhood and social cohesion. For instance men and boys of different Gidaje (plural of Gida) gather for social discourses, eating, reconciliation, etc.

4. It is a place where home-based craft and trade activities, such as weaving, leatherwork, blacksmithing, etc., are carried out ${ }^{41}$

5. It is a mosque as acts of worship such as prayer, meditation, litanies, etc., are performed.

6. It is a school or class for holding lesson ${ }^{41}$

These and many others make a house acquire a central position in the life of Kano people.

\section{The Islam-based principles guiding the} construction of residence in urban Kano

Residential buildings in urban Kano and their structure are traced to originate from the culture and faith of the people. Though some aspects of the residential structure may bear environmental or climatic stamps, greater portion are ascertained to be in conformity with the Islamic ethical principles. This explains why these residential structures are referred to as 'Islam-oriented'. Prominent among these principles include, but are not limited to the following:

1. Audio-visual privacy of inmates is worth safeguarding and protecting.

2. Neighbour's rights are sacred and beyond question.

3. Safeguarding moral integrity of the society is mandatory and not optional.

4. Separation of the sexes is a virtue while illegal and amoral intermingling is an evil.

5. Revering knowledge and scholarship is an act of worship and therefore rewardable. 
6. Guests are blessing to the house. Being always prepared to warmly receive them is a religious obligation.

7. Providing for the needy, the wayfarer, the distressed and even the passer-by is not a burden but a Prophetic precept worth emulating.

8. Social unity and cohesion along with their facilitators are the fabric of happiness, harmony and success which ease the way for the attainment of Allah's pleasure.

9. Consanguinity and affinity are the building blocks of a sober, strong and serene society.

Reflection of these principles on residential structure in urban Kano

1.Audio-visual privacy of inmates is worth safeguarding and protecting.

This is attested to be the purpose of a house not only in Kano but in Hausaland generally. The Zaure, the Soraye, and the Turaka are results of this principle. Zaure serves as an area for seeking permission and it is there that the house owner meets his guest. It is constructed in such a way that the guest is not availed to the inner part of the house. Not a sound or movement from inside the house could be heard there. The Dakali is provided for the guest to wait for the house master or one of the male inmates. By so doing the latter is protected from being seen impromptu before he comes out.

2.Neighbour's rights are sacred and beyond stampede.

In as much as one cares for his own privacy that of his neighbour must also be safeguarded. This is one of the things which explain absence of mulitistorey buildings at the initial stage in this part of the world. When multi-storey buildings emerged their windows were made very narrow and at a height which a very tall person inside the room could not reach. The rearing of domestic animals (such as goats and sheep) and birds (such as chickens and ducks) within the wide open courtyard ensures that a neighbour is not harmed. Similarly, entrances of opposite houses do not directly face each other in order to safeguard neighbour's privacy.

3.Safeguarding moral integrity of the society is mandatory and not optional.

All avenues that will avail non-members of a house to its private realm are blocked by the Zaure and the Soraye. Female members of a house, particularly wives and older female children, are curtailed from being seen by a guest or a passer-by. Female-only ceremonies take place indoors within the open courtyard. In this way adultery and fornication and their preliminaries are substantially curtailed.

4.Separation of the sexes is a virtue while illegal and amoral intermingling is an evil.

One of the functions of Zaure and Soraye is to provide accommodation for older boys. The moment they reach maturity age they now no longer sleep in the private realm of the house. The Soro or Zaure now become their new sleeping place, though they may have access into the house in the day time. Grown-up girls continue to sleep in their respective mothers' rooms till they get married. The wide open courtyard also serves as a female-only venue for social festivities. Here no male non-inmate can see or hear what is going on. Female guest is received by female inmates and the reception area is also inside.

5. Revering knowledge and scholarship is an act of worship and therefore rewardable.

The Zaure serves as a school where different lessons are given. Various branches of Islamic studies, astrology, astronomy and philosophy are studied here. Each student reads his own book while the teacher explains. This type of lesson is generally known in Kano as Karatun Zaure ( the entrance hall lesson). In some cases the Soraye serve as classes where there is a night school (Makarantar dare). The spacious house forecourt, in some areas, functions as children Qur'anic school (Makarantar allo).

6. Guests are blessing to the house. Being always prepared to warmly receive them is a religious obligation.

As receiving guest is considered as a virtue and he/she is seen as a blessing, Kudandan, female guest room, Zaure and Soro provide shelter and warm reception to a guest. Female guest is received inside while a very important guest is received at the Kudandan. If he is a relative or an intimate friend of the house master he sleeps either in the Soro or in the Zaure. A guest never feels belittled by being accommodated in the Zaure or Soro.

7.Providing for the needy, the wayfarer, the distressed and even the passer-by is not a burden but a Prophetic precept worth emulating.

It is an established tradition in Kano that one eats along with others. This is due to the teaching of Islam that blessing lies in feeding or eating along with others. The Zaure and the Filin kofar gida serve this purpose. Food is brought from inside the house to the Zaure in the morning and at noon while dinner is brought to the Filin kofar gida. Breakfast and lunch take place in the Zaure where eating in the sight of the public is avoided. Dinner takes place at the forecourt because it is in the night. In all occasions whoever comes is welcome. In this way an indigent, passer-by, wayfarer, etc., are provided with breakfast, lunch and dinner.

8.Social unity and cohesion along with their facilitators are the fabric of happiness, harmony and success which ease the way for the attainment of Allah's pleasure.

Structure of residence in urban Kano provides for the facilitation of social cohesion, brotherhood and concern. The Filin tsakar gida, Zaure and Filin kofar gida perform this function. Every morning neighbours gathered in the Zaure where Rechauffe or warmed dinner leftover is served as breakfast. This occasion is called 'Cin Dumame'. Similarly, reconciling between disputing parties and resolving conflict in 
the neighbourhood take place in the Zaure. Filin kofar gida serves as a male-only avenue for wedding ceremony, naming ceremony, graduation, funeral services and mourning. The inner open courtyard is a female-only venue for festivities and mourning.

9. Consanguinity and affinity are the building blocks of a sober, strong and serene society.

Many people in Kano operate the extended family system. A number of generations may reside in the same house under mutual assistance, care, respect, love and protection. This explains the provision of a very wide open courtyard. This is an African culture which Islam further encourages. It is observed that:

The compound was the focus of social organization. This responded to the needs of the group. It could be altered to accommodate the fluctuation in family size, extending for a growing family or reducing when someone dies...The traditional courtyard house is never a completed project. As family size increases, more rooms are built on the lot's unused land 42 .

The gradual decline of this type of residence

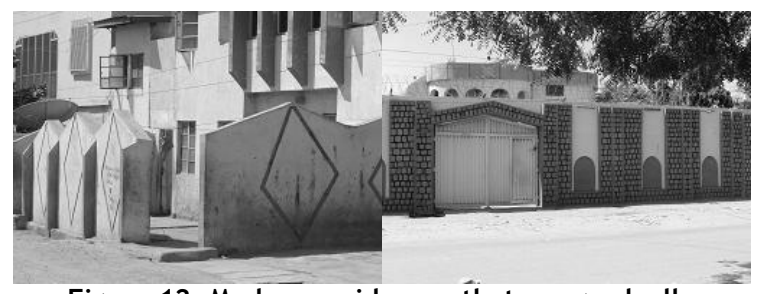

Figure 12. Modern residences that are gradually replacing the traditional islam-oriented ones

This is what used to be a residential structure in urban Kano. It can be referred to as a dual heritage as it combined between the purely traditional and the Islamic. Islamic ethics are successfully integrated in such a way that it led to the eventual creation of a built environment that is humanscaled.

However, with the passage of time, particularly after the debut of colonialism in what is today known as Northern Nigeria, things began to change. The traditional building materials were the first victims of the almighty colonial architecture, followed by the Islam-oriented house structure.

As mental subservience is more fatal than economic servility the colonialists spared no effort and no energy in seeing to it that they not only facilitated the extinction of this Islam-based residential structure but also the gradual wiping away of the philosophy behind its construction ${ }^{43}$. Our architects, policy makers and town planners now fancy the substantially secular-based western architecture which is, as described by one scholar, 'rooted in the abstract and existentialist philosophy, promoting nothing save the distancing of architecture from any spiritual or cultural codification $^{144}$ (Radoine: 2008). This secular architecture is only preoccupied with promoting class divergence, competitiveness, materialism, exotic desires, profit making and unlimited freedom ${ }^{45}$ (Hamouche: 2008). This sad development is further described by as follows:

...We have a situation today in which most people have lost the wisdom and experience that generated the traditional fabric. The link was lost between Islamic cultural identity and its manifestations in the built environment as modern concepts and practices have continued to shape urbanization outside of that rich tradition $^{46}$.

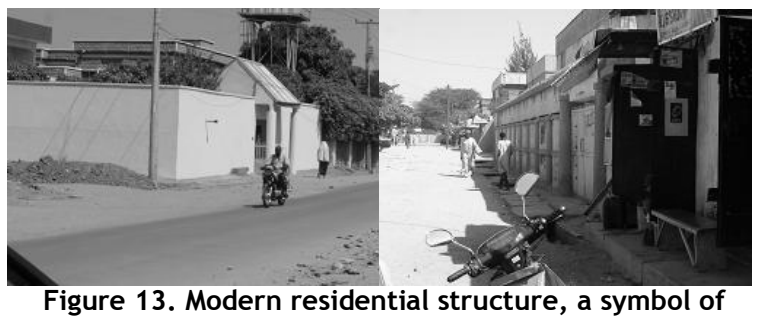
atomism?

Today a schizoid tendency preponderates in Muslim society in which it both strives, though to lesser degree, to maintain its deep attachment to Islam as well as hanker over tasting the fruits of the current order ${ }^{47}$ (Khalid: 2002).

In addition to the invasion of western architecture, other factors which facilitate the gradual decline of these Islam-oriented residential structures include:

- Emphasis on western-style buildings by the government.

- Change of taste on the part of both the affluent and the elite.

- Land fragmentation.

- Inheritance disputes.

- Difficulty in land accessibility.

- Financial constraints

These combine to silently push this heritage to the brink of decline and extinction. This heritage is now being replaced by houses which structure is substantially alien and divorced from the religion and culture of the Kano people. Audio-visual privacy is de-emphasised and regard for the rights of neighbour is now a thing of the past. This is because all barriers such as Zaure, Soro, Kudandan, etc., which safeguard the privacy of the house are now condensed to a very narrow corridor which directly avails those from outside to the private realm of the house. In some cases the sitting room has direct linkage with the inner part of the house and the kitchen. A guest therefore can vividly see and hear what is going on inside. He can also watch the house master's wife while on her way to or from the kitchen. Multi-Storey buildings are constructed with their windows facing the private realm of a neighbour's house. Suck-away are constructed on the road, obstructing public right of passage while power generators are stationed outside polluting the air 
and annoying neighbours with terrible sound. The human scale in these modern houses is forced to give way for the domination of the geometrical one. The brick enclosure isolates one from the people and wanes away from him the spirit of concern for the welfare of others as well as the feeling of social belonging. This symbolizes the replacement of collectivism with individualism or atomism which is repugnant to the Islamic social philosophy.

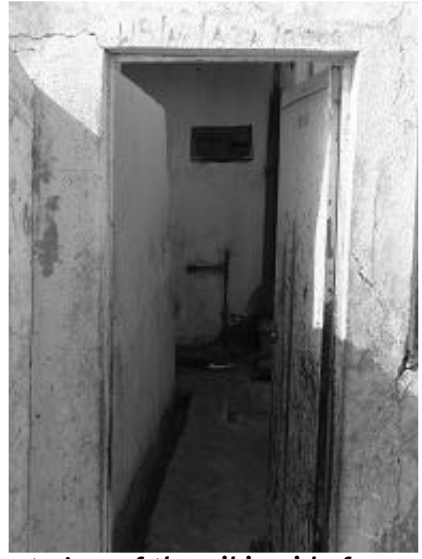

Figure 14. Direct view of the cikin gida from outside. An indication that audio - visual privacy is now a thing of the past

Comparing the traditional Islam-oriented residential structure with the western/modernityoriented one, it becomes clear that in the former a house is conceived as a safeguard for integrity and privacy, an abode for the inmates, a stop-over for the wayfarer, a helping hand for the needy, an avenue for social cohesion, a venue for celebrities, an office for private discussion, a protection for the neighbour's integrity, a haven for societal morality and chastity, a mosque and a school. In the latter, however, a house will be found to be narrowed down to a solitary, a prison, a symbol of uncontrolled freedom, a disturbance to and infringement upon the neighbour's rights, an ostentation, a despair to the wayfarer and a street.

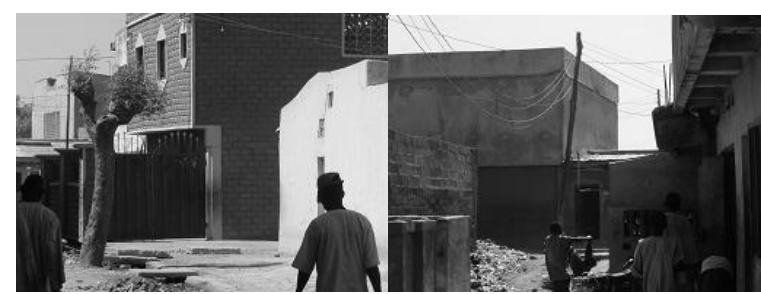

Figure 15. Air pollution, blockage and obstruction of public right of passage

The major difference between the two is that while in the Islam-oriented residential structure a house is divided into three distinct realms; the public, the transitional and the private, the western-oriented one is loosely divided into the public and the private.

All these notwithstanding, it should not be inferred that this paper is clamouring for a return to using the traditional building materials and structure while totally denouncing modern architecture with all its concomitant fruits. What is required is, borrowing the words of one scholar, 'to look back, keep the connection and not loose the track ${ }^{47}$. There are some western structures which need to be incorporated into the indigenous ones and viceversa. There can therefore be a mixture between the two in such a way that while the traditional retains a substantial portion of the residential structure a significant fraction of the building material should continue to be modern. Through this a society maintains a continuous link with its past and at the same time rip the fruits of modernity.

\section{Conclusion}

This paper discussed in some detail the Islamoriented traditional structure of residence in urban Kano. This includes the extent to which they are Islamic and how this heritage is gradually being pushed to the periphery of extinction by modern western architecture in the contemporary city composition.

Going by what is so far discussed the paper concludes that Islam is the pioneer of cities which are ethics-integrated and deeply impacted on the lives of the Kano people including the way they perceive and construct their residences. The structure of western-styled houses which are gradually replacing the Islam-oriented ones in modern Kano city fail to or hardly reflect Islamic values as the traditional ones do. However, the two can be blended together for the emergence of cities that are both traditional and modern.

\section{References}

1. K.Lynch, T.Binns, E.Olofon. 2000. Urban Agriculture Under Threat: the Land Security Question in Kano. www.cityfarmer.org/LandSecurityKano.RTF (Accessed December 17, 2008).

2. Beg. 1983. Two Lectures on Islamic Civilization' in Buaben, J. (nd). "What Makes a Good City? A Muslim Perspective". www. faithforthecity.org.uk/Papers/Islam.pdf(Accessed January 2, 2009).

3. Jomier. 'Islam' The Encyclopedia of Islam in Buaben, J. (nd). "What Makes a Good City? A Muslim Perspective" www.faithforthecity.org.uk/Papers/Islam.pdf(Accessed January 2, 2009).

4. A.Toynbee. 'The Preaching of Islam'. in Buaben, J. (nd). "What Makes a Good City? A Muslim Perspective". www.faithforthecity.org.uk/Papers/Islam.pdf(Accessed January 2, 2009).

5. M.Bridges (nd). "Searching for the Islamic City: the Transformative Power of the Ummah". http://www.writemyline.com/mebridges.com/Isl amic\%20city.pdf (Accessed December 30, 2008).

6. Amir, A. (nd). "Binac al-Daulah al-Muduniyyah" http://news.maktoob.com/article/1963020/-L

(Accessed October 20, 2008). 
7. Y.Al-Qardawi (nd). "Daulah al-Islam Daulah Muduniyyah Marjaciyyatuha al-Islam".

http://www.qardawi.net/site/topics/article.asp? cu no=2\&item no=6088\&version=1\&template id=119\&parent id=13 (Accessed July 13, 2008).

8. K.M. Azab. 2007. "The Jurisprudence of Architecture and Town Planning in Islamic Civilizations".

http://www. isesco.org.ma/Islam.Today/Eng/22/ P5.htm (Accessed May 17, 2007).

9. Shamelah. 2009. "Aqalliyyaht Fiqh". Al-Maktabah al-Shamelah

http: //www.shamelah.ws

10. M.Fauzi. 2008. "Al-hukm al-Islami Wa al-Hurriyyat al-Muduniyyah: Ishkaliyyat Wa Racy". http://seelikethis.blogsport.com/2008/07/blogpost.html (Accessed November 9, 2008).

11. A,Rahman.2005. "Architecture in Islam". http://www.wfim.org.pk/minaret/February2005/arti4.htm (Accessed March 28th, 2009)

12. H. Saremi. 2008. "City from the Perspective of Islam". (A paper presented at International Forum on Islamic Architecture and Design, University of Sharjah, United Arab Emirates)

13. Islamic Art. 2007. "Architecture". [Online]. Available from:

14. M.G.S. Hodgson. 1961. 'The Venture of Islam: Conscience and History in a World Civilisation'. in Bridges, M. (nd). "Searching for the Islamic City: the Transformative Power of the Ummah". http://www.writemyline.com/mebridges.com/Isl amic\%20city.pdf (Accessed December 30, 2008).

15. A.Y. Al-Marzuqi (nd). "Dawr al-Fikr al-Arabi fi Mafhum al-Mujtama ${ }^{c}$ al-Muduni al-Hadith". http://www.aljazeera.net/NR/exeres/3D38BB3B -6B90-47FD-9FF7-3B1DAF3AA247.htm (Accessed October 14, 2008).

16. A. Yahya.2008. "The Impacts of Islamic Culture on Architectural Designs in Hausaland: Focus on the Structure of Residential Buildings". (A paper presented at International Forum on Islamic Architecture and Design, University of Sharjah, United Arab Emirates).

17. A.Ibn Hanbal. 1999. Musannad Al-Imam Ahmad Ibn Hanbal. www.temawiy.com (Accessed July $\left.6^{\text {th }}, 2009\right)$.

18. M. I. Al-Bukhari.2001. Al-Jami' Al-Musannad AlSahih Al-Mukhtasar Min Umuri Rasul Allah Sallallahu Alaihi Wa Sallam Wa Sunanih Wa Ayyamih. www.temawiy.com (Accessed July $3^{\text {rd }}$, 2009).

19. B.S.Hakim,Z.Ahmed. 2006. "Rules for the Built Environment in $19^{\text {th }}$ Century Northern Nigeria". Journal of Architecture and Planning Research. 23:1

20. J.Ahmed.2006. "Introduction to the Islamic city". http://www.1001inventions.com/index.cfm?fuse action=main. viewBlogEntry\&intMTEntrylD=2583 (Accessed February $2^{\text {7th }}, 2009$ ).

21. S.Al-'Uthmani (nd). "Al-Islam wa al-Dawlah alMuduniyyah".

http://www. islamonline.net/servelet/Sattellite? c=ArticleAC\&cid=1173695007452\&pagename $=$ Zon
e-Arabic-Shariah/SRALayout (Accessed October 9, 2008).

22. J.Al-Suyuti (nd). Jami' al-hadith. www.shamelah.ws (Accessed July $7^{\text {th }}, 2009$ ).

23. U.S.Fagge. 2008. "Muhimmancin Hanya a Musulunci". (A lecture delivered at sensitization meeting jointly organized by ministry of land and survey, Kano state, K.N.U.P.D.A. and R.E.M.A.S.A.B., Kano State).

24. M.Sha'lan (nd). "Al-Mujtama ${ }^{c}$ al-Muduni Fi ${ }^{\mathrm{C}} \mathrm{Asr}$ alRasul".http://www.ahlalquran.com/arabic/prin tpage.php?main

25. H.Rahoui.2008. "Islamic Influence in Architectural and Urban Design for a Sustainable Islamic Architecture Integrated into the Present Rules". (A paper presented at International Forum on Islamic Architecture and Design, University of Sharjah, United Arab Emirates).

26. A. Ezzati.1979. An Introduction to the History of the Spread of Islam. Lagos: Islamic Publications Bureau

27. J.E.C. Philips.1986. "A History of the Hausa Language". in Barkindo, B.M. () Kano and Some of her Neighbours (ed). Zaria: Ahmadu Bello University Press Limited.

28. I.Sulaiman.1986. A Revolution in History the Jihad of Usman Danfodio. London: Mansell Publishing Limited.

29. S.I.K/Nassarawa. 2006. Dafin Boko da Maganinsa Kano: K2 Graphics and Design.

30. U.Bugaje.2004. "Sheikh Uthman Ibn Fodio and the Revival of Islam in Hausaland". http://www.webster.co.uk/ ubugaje/shyri.html (Accessed August 3, 2006).

31. M.Adamu.1978. The Hausa Factor in West African History. Zaria: Ahmadu Bello University Press Limited.

32. H.T. Sa'ad.1986. "Continuity and Change in Kano Traditional Architecture". in Barkindo, B.M. Kano and Some of her Neighbours (ed). Zaria: Ahmadu Bello University Press Limited.

33. J.Ahmed.2006. "Introduction to the Islamic city".http://www.1001inventions.com/index.cfm ?fuseaction=main. viewBlogEntry\&int MTEntrylD=2 583 (Accessed February 27 ${ }^{\text {th }}, 2009$ ).

34. A.S. Barau.2006. An Account of the High Population in Kano State. Kano: Concern Group for Justice and Fairness.

35. I.A. Kurawa (nd). About Kano. (ed.) Kano: Research and Documentation Directorate.

36. R.M. Mavrakis.2008. " Urban Design Principles and Guidelines for the Development of Islamic Cities". (A paper presented at International Forum on Islamic Architecture and Design, University of Sharjah, United Arab Emirates).

37. F.W.Taylor,A.G.G.Webb.1932. 'Labarun Al'adun Hausawa da zamantakewarsu: Accounts and Conversations Describing Certain Customs of the Hausas' in Monghtin, J.C. "The Friday

38. A.M.Oumar.2007. "Tsattsaki: The essence of Hausa urban domestic architecture. (Unpublished).

39. Islamic Art .2007. "Architecture". 
http: / /islamicart.com/main/architecture/future .html (Accessed December 3, 2007).

40. A.A.M.Oumar (nd). "Duniya da Lahira: The house, the home and concept of the ideal life. (Unpublished).

41. H.J. Nast.1992. "Space history and power: Stories of spatial and social change in the palace of Kano, Northern Nigeria, Circa 1500-1900". (Unpublished Ph.D thesis) Quebec: McGill University, Montreal

42. Yale.1993. "African traditional architecture". http://www.yale.edu/ynhti/curriculum/units/19 93/1/93.0.1.10x.html (Accessed February 9th, 2008).

43. D.Feroz. 2008. "Alaqah hawiyyah al-insan bi alimarah wa al-umran". (Unpublished paper presented at International Forum on Islamic Architecture and Design, University of Sharjah. 2008).

44. H.Radoine.2008. "Architecture in the spirit of Islam". (Unpublished paper presented at International Forum on Islamic Architecture and Design, University of Sharjah. 2008).

45. M.B.Hamouche.2008. "Islamization of contemporary architecture: Shifting the paradigm of Islamic architecture".

46. F. M.Khalid.2002. "Islam and the environment". Social and Economic Dimensions of Global Environmental Change. Vol.5, PP. 332-339.

47. A.Siddiqui.2009. "Believing and belonging in a pluralistic society: Exploring resources in Islamic traditions".http://www.mihe.org.uk/mihe/detail .php?page $=176 \mathrm{\&} s=2011 \quad\left(\right.$ Accessed February $7^{\text {th }}$, 2009). 